\begin{tabular}{|l|l|l||}
\hline \multicolumn{2}{|c|}{ PublisherInfo } \\
\hline \hline PublisherName & $:$ & BioMed Central \\
\hline \hline PublisherLocation & $:$ & London \\
\hline \hline PublisherImprintName & $:$ & BioMed Central \\
\hline \hline
\end{tabular}

\title{
US genetic policy panel forms
}

\begin{tabular}{|l|l|l||}
\hline \multicolumn{2}{|c|}{ ArticleInfo } \\
\hline \hline ArticleID & $:$ & 4789 \\
\hline \hline ArticleDOI & $:$ & $10.1186 /$ gb-spotlight-20030612-01 \\
\hline \hline ArticleCitationID & $:$ & spotlight-20030612-01 \\
\hline \hline ArticleSequenceNumber & $:$ & 141 \\
\hline \hline ArticleCategory & $:$ & Research news \\
\hline ArticleFirstPage & $:$ & 1 \\
\hline \hline ArticleLastPage & $:$ & 3 \\
\hline \hline & & RegistrationDate : 2003-6-12 \\
\hline ArticleHistory & $:$ & OnlineDate \\
\hline \hline ArticleCopyright & $:$ & BioMed Central Ltd2003-6-12 \\
\hline \hline ArticleGrants & $:$ & \\
\hline \hline ArticleContext & $:$ & 130594411 \\
\hline \hline
\end{tabular}




\section{Peg Brickley}

Email: pegbrickley@hotmail.com

Today marks the launch of a new panel on genetics and social policy created by the Bush administration during a reorganization of the science advisory system that critics say is being transformed into a showcase of conservative causes in which science takes a back seat to religious ideology.

Appointees to the Secretary's Advisory Committee on Genetics, Health, and Society include Republican analyst and health lobbyist Cindi Berry, a former speechwriter for Senator Bill Frist (Republican-Tennessee), the Senate majority leader. Also on the panel is C. Christopher Hook, director of ethics education at Mayo Graduate School of Medicine. A founding member of Do No Harm, The Coalition of Americans for Research Ethics, Hook is active in Christian medical groups and has testified before Congress that embryonic stem cell research amounts to a "license to kill."

"I believe that embryonic stem cell research is unethical and unnecessary from the standpoint of providing therapies and cures for patients," Hook told us in an interview yesterday. "There's no question that there may be certain scientific questions that may not be able to be answered without going to embryonic stem cells, but I think we can accomplish those goals without crossing the ethically troublesome line."

Over the past year, the Department of Health and Human Services has shut down some committees, created others, and shook up science advisory panels.

"I believe the Bush administration faced a situation where there were a number of advisory committees that exceeded the number under the Federal Advisory Committee Act," said Edward R.B. McCabe, the University of California, Los Angeles physician named to chair the committee. "They wanted to develop their own agenda and not be restricted."

McCabe was originally appointed by the Clinton administration to chair the now-shuttered committee on genetic testing. He is one of two holdovers from the Democratic era on the new genetics policy panel, which will consider topics including embryonic stem cell research.

Ronald Green, director of the Ethics Institute and chair of the religion department at Dartmouth College, said the reorganization of the advisory panel system "is not surprising because these issues around genetics, reproductive medicine are at the forefront of the agenda that is driving this administration. This is an area where you can make great political gains with relatively little public understanding or awareness."

In sessions today and tomorrow, the new committee will develop its priorities. McCabe has in the past backed "therapeutic cloning," a term that under some but not all definitions extends to use of embryonic stem cells. "Since I learned I would be chairing the secretary's advisory committee, I have tried to remain neutral," McCabe said.

But while pundits and scientists jockey for position on the policy circuit, market forces this week voted for the future of embryonic stem cells. Geron Corporation on Tuesday (June 10) announced that it had won a patent for technology to make future therapies based on human embryonic stem cells safer by 
allowing scientists to separate differentiated cells from undifferentiated cells in batch preparations. The news sent the stock up sharply to a closing price of $\$ 7.98$ per share, a 1-day gain of $15 \%$ and a healthy level for a stock that was selling for $\$ 1.73$ per share in mid-March.

Promising news on Geron's other lead line of development, telomerase technology for cancer treatment, accounts for some of the recent rise. But yesterday's gains suggest that biotech investors believe politics will eventually give way to the success of stem cell science in treating heart disease, spinal cord injuries, Parkinson disease, and other disorders.

Just this morning (June 11), Geron announced that the UK's Human Fertilization and Embryology Authority had granted the Roslin Institute permission to derive new human embryonic stem cell lines from donated embryos created for in vitro fertilization.

"Is there an uncertain environment as to what is happening with stem cells in the future? Sure. But the best way to reduce that uncertainty is to present good data," David Earp, Geron's vice president for intellectual property, told us yesterday.

\section{References}

1. Secretary's Advisory Committee on Genetics, Health, and Society, [http://www4.od.nih.gov/oba/ sacghs/roster/SACGHSmembers.htm]

2. Cindi Berry, [http://www.wexlergroup.com/]

3. C. Christopher Hook, [http://www.mayo.edu/research/people/6/6903_hook/]

4. Do No Harm: The Coalition of Americans for Research Ethics, [http://www.stemcellresearch.org/]

5. C. Christopher Hook's testimony before House Government Reform Subcommittee on Criminal Justice, Drug Policy and Human Resources, July 17, 2001., [http://www.stemcellresearch.org/ testimonies/hook.htm]

6. Edward R.B. McCabe, [http://www.pediatrics.medsch.ucla.edu/peds/pediatrics/fac_prof/ exec_chair.html]

7. Ronald Green, [http://www.dartmouth.edu/ ethics/faculty.html]

8. "Geron receives US patent for pluripotent stem cells modified for therapeutic applications," Geron press release, June 10, 2003., [http://biz.yahoo.com/bw/030610/105271_1.html]

9. "Geron Announces UK Authorization for Stem Cell Derivation," Geron press release, June 11, 2003., [http://biz.yahoo.com/bw/030611/115154_1.html]

This PDF file was created after publication. 